\title{
The Leathery Turtle
}

\section{Robert Bustard}

The author suggests that the leathery turtle, the world's largest species, is seriously endangered despite the discovery a few years ago of a big new rookery in French Guiana. He urges that part of the only other known large rookery - at Trengganu, in Malaysia - should be declared a national park, where tourists would be encouraged under careful supervision, and a much increased hatchery programme initiated by the government.

The leathery turtle, luth or leatherback, is not only by far the largest living member of the Order Testudines, but is the sole living representative of its family - the Dermochelidae. It attains a carapace length of about six feet and a weight of up to $1400 \mathrm{lbs}$. It is the most remarkable of the world's sea turtles being pelagic, and hence much more highly specialised to life in the oceans than any other species. A heavy, domed shell, such as characterises land tortoises, would be a severe handicap in the water, so it is not surprising that the shells of all sea turtles have become streamlined and the thickness of their armour reduced. However, in the leathery turtle the horny outer layer and the bony shell have almost completely disappeared and have been replaced by superficial platelets which occur in the leathery skin. A characteristic of Reptilia is that their skin is covered with scales or granules. These are obvious on the heads and flippers of all species of sea turtle except the leathery turtle, in which they occur only in the hatchlings and are lost soon after hatching. Its various specialisations, together with the lack of any close living relatives, make the leathery turtle unique. While the loss of any species is most regrettable, the loss of such a distinctive form as the leathery turtle - sole representative of a family - would be tragic.

In 1961 Oryx drew attention to the extremely small size of leathery turtle populations worldwide (vol.6, page 116). Although we now know that numbers must be considerably higher than was suspected then, there is no reason to be confident about the future of this remarkable animal.

The leathery turtle is known to nest in small numbers in several places, including the Mexican Pacific coast and Matina in Costa Rica, and on the Tongaland coast of Natal, South Africa, where it is totally protected; but there are only two large rookeries: in Trengganu, on the east coast of West Malaysia, and a recently discovered one in French Guiana, South America, where Peter Pritchard, the discoverer, tagged seventy-four leathery turtles in a single night in June 1969. Clearly it is a major rookery, and its discovery was undoubtedly extremely good news for the species. Pritchard reports that the nesting beach is remote and difficult to reach even from the sea, and the turtles are now completely protected.

The Trengganu rookery, however, which is well known, particularly 
through the writings of Dr. Hendrickson and the late Dr. Balasingham, gives serious cause for concern. Two years ago about 80 leathery turtles nested per night on a nine-mile stretch of beach; in 1971 the figure was only about 30 on a good night. Hendrickson initiated the leathery programme at Trengganu in 1961, and this, combined with the extremely efficient manner in which virtually 100 per cent of the remaining eggs are harvested for human consumption, tends to cover up the serious consequences to the future of the rookery.

Certainly the future of the leathery turtle is tied to conservation at these two key rookeries, unless another equally important one remains to be discovered.

The leathery turtle has suffered by not having a champion. Most other species have a worker or workers involved in long-term studies on the species who are also well placed politically to campaign for their conservation. Professor Carr in his book The Turtle wrote that the leathery turtle 'may have the least dreary outlook' of the sea turtles, and in $1969 \mathrm{Dr}$. Pritchard wrote that the leathery turtle 'may be the least seriously threatened of the sea turtles'. I doubt it.

Estimates of sea turtle populations are usually given in terms of breeding females, since males are seldom encountered (being entirely aquatic) and it is meaningless to consider juveniles, most of which are eaten by predators. Although no reliable estimates of the world population of the leathery turtle exist (they should be sought), it would seem that a figure of 20,000 breeding females may be a resonable guess, and may even turn out to be slightly conservative. Such an estimate is in line with the known facts presented by Pritchard (in press). But even with this estimate it can still be stated quite definitely that it is not the least threatened species. For instance, I recently estimated the breeding population of green, flatback and loggerhead turtles in the single state of Queensland, Australia as not less than 75,000 (Oryx, September 1970 , page 281), and as there are also substantial turtle populations in Western Australia and the Northern Territory, the green turtle population of Australia alone is much higher than the world population of the leathery turtle. Moreover, in Australia green turtles have a secure future through conservation - fully protected in Queensland, like all other sea turtles, and the Northern Territory, and strictly controlled in Western Australia, where only two licensees take turtles. In Trengganu the leathery turtle is grossly over-exploited, and we cannot be complacent about the future of the French Guiana rookery.

The IUCN Red Data Book lists the leathery turtle, like the hawksbill, in category 1 (the highest priority), defined as 'endangered, actively threatened with extinction; continued survival unlikely without' the implementation of special protective measures'. Moreover, it is the only turtle to be 'star listed', meaning critically endangered.

\section{Trenggannu Rookery}

I visited the Trengganu rookery at the end of July 1970 in order to have up-to-date information for this article. At the IUCN Sea Turtle Specialists working meeting in Switzerland, in March 1969, it was recommended, by myself and others, that attempts be made to greatly increase the number of eggs being safeguarded in the Trengganu 


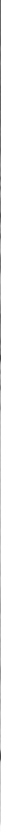

Above LEATHERY TURTLE laying eggs on the beach at Trengganu, in Malaysia: The legs of the onlookers give some idea of the animal's great size.

Below Eggs being collected as they are laid.

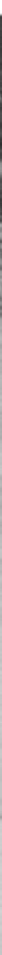


hatchery by, if necessary, providing funds to buy eggs for a period of years; no action has yet resulted, but discussions are going on.

The nine miles of nesting beach at Trengganu are divided into three portions each of three miles, and the right to collect eggs on these is subject to tender each year. During 1970 the tender for the favoured beach was $\$ M 18,000$ and for the other two beaches $\$ M 13,000$ each (7.3 Malaysian dollars to the $£$ ). In 1970 the selling price of each egg was 17 cents. Hence an average clutch of about 120 eggs is worth $\$ 20$ and an average night's take on the $\$ 18,000$ beach, consisting of between twenty and thirty nests, is worth up to 185 .

Having paid the tender, the licensees naturally collect every nest, and egg collection is virtually 100 per cent. The only eggs left to hatch are those in the hatchery. Up till 1970 the hatchery has held up to 15,000 eggs which is a meagre 2 per cent of the egg lay. One does not need any specialised ecological training to realise that if 98 per cent of the eggs are destroyed, and the young which emerge from the remaining two per cent left to face the multitude of marine predators, the population is rapidly on the way to extinction.

Hatchery operations usually result in a lower percentage egg hatch than if the eggs were left to hatch in the sand naturally (see discussion in Bustard, 1970), although Balasingam reported that he had increased the percentage hatch by re-burying the eggs in smaller batches, of about 50 , compared with $80-110$ in the natural nests. It is my belief that every effort should be made now to increase the percentage of the eggs in the hatchery to an effective 15 per cent of the natural egg lay. In 1970 an attempt was to be made to increase the hatchery from 15,000 to 40,000 eggs. Even if this meritorious aim were achieved this would only be 5 per cent of the natural egg lay, with no allowance for reduced hatch, or less than one-third of what I consider minimal figures. Incidentally, for those interested in 'buying out' the local egg production, the cost in 1970 would have been around $£ 21,500$.

With other sea turtles it is possible and more effective to tackle the problem from the other end by protecting the newly hatched young, but unfortunately the hatching Dermochelys, like the adults, are extremely difficult to keep in captivity.

The compromise solution of the problem, which should be acceptable to all parties, is to make part of the Trengganu rookery area into a national park and fence it. This should be the three miles adjacent to the fishing village approximately eleven miles north of Dungun. The remaining two beach areas could be let annually for tender, subject to not less than an effective 15 per cent of the eggs being maintained in hatcheries set up on each beach and run under Government supervision as with the present hatchery. The cost of the greatly increased hatchery scheme should be met, at least in part, by an increase in the price of the tenders. During 1970 the three tenders brought in $\$ M 44,000$ and the sale of eggs would realise an estimated \$M157,000. There would seem to be scope for some reduction in this margin.

The national park would have full-time wardens during the nesting season, and the local village which at present makes an income from the eggs, would have the exclusive right to provide guides. Visitors to the 
Leathery Turtle National Park would be required to pay an admission fee and to hire a local guide, so that they could see the turtles without disturbing them. An Australian staying at my rest house tipped a waiter f2 to accompany him to the beach. Had only local villagers had the franchise to act as guides this money would have gone to the village.

In order to set up such a national park funds would have to be provided during a 'transition' period to buy some of the eggs for the increased hatchery programme, and possibly to provide expert advice.

Promotion of the national park would be essential. Trengganu is quite undeveloped and there is very little tourism, although the potentialities of the state are enormous. Here would seem to be a great opportunity for conservation organisations to (a) help the conservation of a unique world-wide species by promoting a key area as a National Park and (b) foster conservation-minded development which would help the local people without adversely affecting the local biota.

Turtles are key tourist attractions. Australians have long known this on the Great Barrier Reef and it is an important factor in their conservation. But Trengganu is the only place in the world with large populations of a really giant turtle, apart from the relatively inaccessible French Guiana beach.

\section{REFERENCES}

BUSTARD, H.R. 1970. Turtles and an Iguana in Fiji. Oryx 10:317-322.

BUSTARD, H.R. (in press). Sea Turtles: Ecology and Conservation Collins, London CARR, A. 1968, The Turtle. Cassell, London.

ANON, 1961. The leathery turtle or luth. Oryx 6:116-125.

PRITCHARD, P.C.H. 1969. Sea turtles of the Guianas. Bull.Fla.State Mus. Biol.Sci. 13: 85-140.

PRITCHARD, P.C.H. (in press). The leatherback turtle, Dermochelys coriacea. IUCN Publs.

\section{Dugong in Mozambique}

Dugong still have much the same distribution in Mozambique although with some decline in numbers, according to George Hughes who made a survey in the territory in 1970 in conjunction with a sea-turtle survey. He found one of the greatest concentrations in the Antonio Enes estuary and nearby coast, which he describes in Biological Conservation. In two flights which did not cover the entire estuary, he counted 27, 12 of them in one herd. A fisherman reported ha ring seen one herd of about 30 animals, six being the more usual number. Fishing pressure on the dugong is not great but he would like to see the area made into a dugong sanctuary.

\section{Sea Bird Reserve}

The Salvagens Islands, 150 miles from Madeira, have been made a nature reserve in a rather unusual way. The World Wildlife Fund had negotiated their purchase with the owner when the Portuguese Government stepped in, bought the islands and declared them a nature reserve. All hunting and egg collecting have been prohibited. The large colonies of breeding sea birds include Cory's and Madeiran little shearwaters, frigates, and Bulwer's and Madeiran storm petrels. 


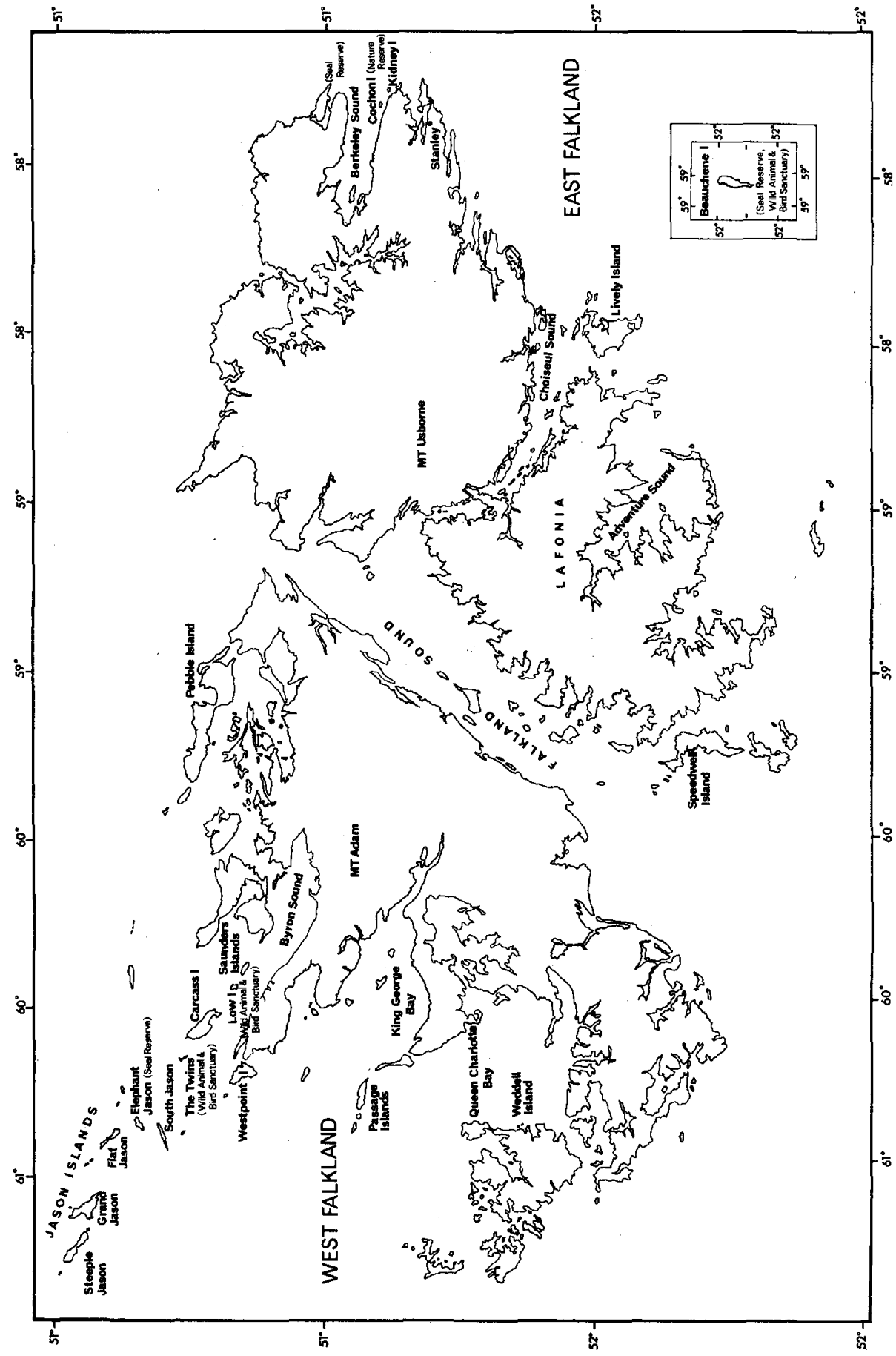

